\title{
Tissue and whole-body oxygen uptake in fed and fasted steers
}

\author{
BY J. H. EISEMANN AND J.A. NIENABER \\ US Department of Agriculture, Agricultural Research Service, Roman L. Hruska Meat Animal \\ Research Center, PO Box 166, Clay Center, Nebraska 68933, USA
}

(Received 5 December 1989 - Accepted 3 May 1990)

\begin{abstract}
The effect of feeding $v$. fasting, on tissue blood flow, oxygen uptake and proportional contributions of the portal drained viscera (PDV), liver (Expts 1 and 2) and hindquarters (HQ; Expt 2) to whole-body $\mathrm{O}_{2}$ uptake were studied in beef steers. The combined techniques of indirect calorimetry and net tissue flux, the latter being the product of arterio-venous concentration difference and blood flow, were used in the experiments. In response to fasting, whole-body $\mathrm{O}_{2}$ consumption decreased as did $\mathrm{O}_{2}$ uptake by all measured tissues except the liver (trend only in Expt 1). Blood flow to all measured tissues decreased during fasting and fractional uptake of $\mathrm{O}_{2}$ decreased in PDV and increased in liver and HQ (Expt 2). Proportional contribution of specific tissues to whole-body $\mathrm{O}_{2}$ uptake changed when animals were switched from the fed to the fasted state. The percentage consumed by PDV decreased from 25.4 to 19.9, by liver increased from 20.5 to 26.4 and by HQ was unchanged (9.6 and 10.5) in Expt 2. These significant responses in Expt 2 were observed as trends in Expt 1. The changes in proportional contribution of tissues to whole-animal $\mathrm{O}_{2}$ uptake reflect the changing metabolic role of specific tissues to lack of food supply. These findings emphasize the central role of the liver in metabolism and indicate that fasting (catabolic) measurements may not reflect the previous fed (anabolic) physiological state.
\end{abstract}

Blood flow: Fasting: Oxygen uptake: Cattle

Oxygen consumption by a tissue is an index of aerobic energy use by the tissue. $\mathrm{O}_{2}$ consumption by the portal-drained viscera (PDV) varied directly with level of intake in beef steers (Huntington et al. 1988) and lambs (Burrin et al. 1989) and decreased in dairy cows in response to fasting (Lomax \& Baird, 1983). $\mathrm{O}_{2}$ consumption by the liver was positively related to level of intake in lambs (Burrin et al. 1989) and decreased during fasting in dairy cows (Lomax \& Baird, 1983). Similarly, whole-animal $\mathrm{O}_{2}$ consumption or heat production is directly related to level of intake in cattle (Lobley et al. 1987) and lambs (McBride \& Milligan, $1985 \mathrm{~b}$ ), reflecting the general decline in metabolic rate of body tissues as energy intake declines. Simultaneous determination of tissue and whole-body $\mathrm{O}_{2}$ consumption allows calculation of the relative contribution of individual tissues to whole-body $\mathrm{O}_{2}$ use.

Whole-animal $\mathrm{O}_{2}$ consumption has been determined in fasted animals to assess the effect of treatment on basal energy requirements (e.g. Rumsey et al. 1980), thus using a catabolic state to make inference to an anabolic physiological state. Level of energy intake before fasting has been shown to affect fasting heat production (FHP) and parallel changes in weight of several visceral tissues, including the gastrointestinal tract and liver (for review, see Ferrell, 1988). The objectives of these studies were to measure proportional $\mathrm{O}_{2}$ uptake by the PDV, liver and hindquarters (HQ) of steers and determine whether proportional uptake by individual body tissues varies between fed and fasted steers. In Expt 2 we included measurement of nitrogen flux across splanchnic tissues to quantify additional metabolic changes in response to fasting. 


\section{MATERIALS AND METHODS}

\section{Animals and diets}

Six MARC III (1/4 Hereford, 1/4 Angus, 1/4 Pinzgc ur, 1/4 Red Poll) steers were used in Expt 1. They were fed on a high-energy diet (Table 1) at $6 \mathrm{~h}$ intervals, beginning at 07.00 hours. The estimated metabolizable energy $(\mathrm{ME})$ and crude protein $(\mathrm{N} \times 6.25 ; \mathrm{CP})$ intakes (calculated from measured intake of feed) were $64.6 \mathrm{MJ} / \mathrm{d}$ and $955 \mathrm{~g} / \mathrm{d}$ respectively during measurements in the fed state.

Six Simmental $\times$ Hereford steers were used in Expt 2. They were fed on a low-energy diet (Table 1) at $6 \mathrm{~h}$ intervals. The estimated ME and CP ntakes were $94.4 \mathrm{MJ} / \mathrm{d}$ and $1107 \mathrm{~g} / \mathrm{d}$ respectively during measurements in the fed state. In both experiments the $\mathrm{CP}$ concentration of the diet was adjusted so that protein intake would tot limit gain at either level of energy intake (National Research Council 1984). All steers were housed in individual stalls throughout the experimental period. Water was available ad lib.

\section{Surgery}

Steers were fasted for $48 \mathrm{~h}$ and water removed $24 \mathrm{~h}$ before surgery to install chronic indwelling catheters in the abdominal aorta, hepatic-portal vein, an hepatic vein, branches of the cranial mesenteric vein (Expts 1 and 2), and the caudal vena cava (Expt 2 only). An ultrasonic flow probe (diameter $16 \mathrm{~mm}$; Transonic Systems, Inc., Ithaca, NY) was placed around the abdominal aorta for measurement of blood flow to the HQ (Expt 2). Procedures for catheterization of the splanchnic tissues were similar to those described by Huntington et al. (1989). Placement of the ultrasonic flow probe was as described by Eisemann et al. (1988) except access was through an incision on the right side of the steer. Insertion of a catheter in the caudal vena cava was accomplished by direct access to the vessel through the visceral cavity.

The experiment began several months after surgery, following completion of another experimental protocol. For Expt 1 all six steers had jatent catheters in the hepatic-portal vein and five had patent catheters in the hepatic vein. In the previous protocol two of the steers received clenbuterol ( $8 \mathrm{mg} /$ animal per d) for a 3 week period ending 5 weeks before initiation of the present protocol. For Expt 2 all six steers had patent catheters in the hepatic-portal and hepatic veins, and four steers had patent catheters in the vena cava. In the previous protocol each steer received injections of bovine somatotropin for $10 \mathrm{~d}$ ending 9 weeks before initiation of the present protocol.

\section{Experimental desiysn}

Expts 1 and 2 were conducted in identical fashion. The afternoon before measurements each steer was moved to a stall having an associated respiration box for measurement of whole-animal gas exchange. The box measured $0.9 \mathrm{~m} \times 0.9 \mathrm{~m} \times 1.8 \mathrm{~m}$ and was fitted with a waterer and feed box so that either fed or fasting measurements could be conducted. A $0.6 \mathrm{~m}^{2}$ section of the front and each side of the box were covered with $5 \mathrm{~mm}$ Plexiglass for visibility. One side also held an access door. The remainder of the box was covered with $3 \mathrm{~mm}$ aluminium sheeting. The $0.4 \mathrm{~m}$ wide opening for the animal's head was fitted with a reinforced vinyl hood to provide a seal around the animal's neck using a pair of draw strings. There was sufficient amount of material in he hood to allow the animal to lay down. All steers had previous experience in the respiration box. The side door on the respiration box remained open until the start of mesisurements the following morning at 07.30 hours. From 07.30 to 13.30 hours simultaneous measurements were made of whole- 
Table 1. Composition of the diet for each experiment ( $\mathrm{g} / \mathrm{kg}$ dry matter)

\begin{tabular}{|c|c|c|}
\hline Ingredients & Expt $1^{*}$ & Expt $2 \dagger$ \\
\hline Smooth brome (Bromus inermis) chopped hay & - & $300 \cdot 0$ \\
\hline Cracked majze & $649 \cdot 9$ & $490 \cdot 0$ \\
\hline Ground lucerne (Medicago sativa) hay & $122 \cdot 5$ & $78 \cdot 6$ \\
\hline Soya-bean meal & $150 \cdot 0$ & $84 \cdot 0$ \\
\hline Molasses & $50 \cdot 0$ & $29 \cdot 9$ \\
\hline Urea & $9 \cdot 6$ & - \\
\hline $\mathrm{CaCO}_{3}$ & $12 \cdot 5$ & $11 \cdot 9$ \\
\hline $\mathrm{NaCl}$ & 4.9 & 49 \\
\hline Trace mineral premix + & $0 \cdot 5$ & 0.5 \\
\hline Vitamins $A, D, E \S$ & $0 \cdot 2$ & 0.2 \\
\hline
\end{tabular}

* Crude protein (nitrogen $\times 6.25$ ) $183 \mathrm{~g} / \mathrm{kg}, 12.38 \mathrm{MJ}$ metabolizable energy $/ \mathrm{kg}$ dry matter.

$\uparrow$ Crude protein $132 \mathrm{~g} / \mathrm{kg}, 11 \cdot 25 \mathrm{MJ}$ metabolizable energy $/ \mathrm{kg}$ dry matter.

+ Provided (mg/kg dry matter): iron 50, manganese 40, zinc 60 , copper 8 , iodine 1 , cobalt 0.5 .

$\S$ Provided ( $\mu \mathrm{g} / \mathrm{kg}$ dry matter): vitamin A (retinol) 529, vitamin D 4.4, vitamin E 176.

animal gas exchange and tissue $\mathrm{O}_{2}$ uptake. All tissue samples were taken while the steers were standing, to ensure uniformity in sample collection, and encompassed a $4 \mathrm{~min}$ interval. The steers were allowed to lay down in between samples but did not always do so. When they did lay down, at least 5 min were allowed in between getting an animal up and sampling. Changes in HQ blood flow in response to standing occurred over approximately a $30 \mathrm{~s}$ interval. Following measurements each steer was returned to its original stall. A second set of measurements was made 2 weeks later after steers were fasted for $3 \mathrm{~d}$. The $6 \mathrm{~h}$ measurement period corresponded to $78-84 \mathrm{~h}$ post feeding.

\section{Experimental procedures}

Indicator dilution ( $p$-aminohippurate, $\mathrm{PAH}$ ) was used to measure blood flow in PDV and hepatic tissues. On each sample day a primed continuous infusion of PAH was initiated into a branch of the cranial mesenteric vein at least $45 \mathrm{~min}$ before the first set of simultaneous blood samples. The infusion rate of $\mathrm{PAH}$ varied with the size of the steers and feeding status and was 7200 and $3600 \mathrm{mg} / \mathrm{h}$ for fed and fasted steers respectively in Expt 1; and 8640 and $5400 \mathrm{mg} / \mathrm{h}$ for fed and fasted steers respectively in Expt 2 .

There were three whole-body gas exchange measurements of $2 \mathrm{~h}$ duration during the $6 \mathrm{~h}$ sampling period. The first measurement began at 07.30 hours, 30 min after the 07.00 hours feeding (in the fed state). Air was circulated within the respiration box and exhausted through a dry test meter. A proportional sample of the exhaust air and a concurrently collected sample of intake air were held in Tedlar bags. The samples were taken to gas analysers for determination of oxygen, carbon dioxide and methane concentrations as outlined in Nienaber \& Maddy (1985). The system recovery of $\mathrm{O}_{2}$ and $\mathrm{CO}_{2}$ exchange averaged 99 (SE 3.0) and 98 (SE 3.5) \% respectively, as measured by combustion of alcohol within the box. Loss of energy as heat was calculated from $\mathrm{O}_{2}$ consumed and $\mathrm{CO}_{2}$ produced with correction for $\mathrm{CH}_{4}$ production (Brouwer, 1965) and extrapolated to $24 \mathrm{~h}$ for comparison with literature values reported on that basis.

Within each whole-body measurement period, four sets of blood samples were taken simultaneously from the abdominal aorta, hepatic-portal vein, hepatic vein (Expts 1 and 2) and caudal vena cava (Expt 2 only) at 30 -min intervals beginning at 07.45 hours. Two blood samples were taken. The first was withdrawn anaerobically into 3-ml heparinized syringes, capped with a rubber stopper and kept on ice until analysed for $\mathrm{O}_{2}$ saturation and 
haemoglobin $(\mathrm{Hb})$ content using a Hemoximeter (OSM 2; Radiometer Corporation, Copenhagen, Denmark). These analyses were completed within $30 \mathrm{~min}$ of sampling. $\mathrm{O}_{2}$ concentration was calculated by the following equation:

$$
\mathrm{O}_{2}(\mathrm{~mm})=\frac{\left(\mathrm{Hb}(\mathrm{g} / \mathrm{l}) \times 1.34 \mathrm{ml} \mathrm{O} / \mathrm{g} \mathrm{Hb} \times \% \mathrm{O}_{2} \text { saturation } / 100\right)}{22.4 \mathrm{mlO}_{2} / \mathrm{mmol} \mathrm{O}_{2}}
$$

A second $5 \mathrm{ml}$ blood sample was taken using a heparinized syringe. Blood from this sample was diluted $1: 3(\mathrm{v} / \mathrm{v})$ with deionized distilled water and refrigerated until analysed for PAH. Blood flow was calculated by the following equation:

$$
\text { blood flow }(1 / \mathrm{h})=\frac{\text { PAH infusion rate }(\mathrm{mg} / \mathrm{h})}{[\mathrm{PAH}]_{\mathrm{V}}-[\mathrm{PAH}]_{\mathrm{A}}},
$$

where V is PAH concentration in the hepatic-portal vein (PDV flow) or hepatic vein (hepatic flow) and $\mathrm{A}$ is PAH concentration in the artery (background). Hepatic arterial flow is hepatic flow minus PDV flow. For Expt 2 only, ammonia- $\mathrm{N}$, urea- $\mathrm{N}$ and $\alpha$-amino$\mathrm{N}$ were analysed also on the second blood sample. In addition the ultrasonic flow probe was used for measurement of blood flow to the HQ during the blood sampling interval. Blood flow was recorded every 10 s over the blood sampling interval and an average flow was then calculated. All analyses were completed on the day of sampling by automated procedures (Technicon Industrial Systems, Tarrytown, NY) as follows: PAH (Technicon Industrial Systems, 1972), ammonia-N by a hypochlorite method (Technicon Industrial Systems, 1974), urea-N by a diacetylmonoxime method (Technicon Industrial Systems, 1977) and $\alpha$ amino- $N$ by the method of Broderick \& Kang (1980) modified to include sample dialysis. Under these conditions $N$-acetyl-PAH is not detected across the hepatic bed of cattle.

For tissue $\mathrm{O}_{2}$ and metabolite measurements, a mean value was calculated for each four samples corresponding to a whole-body measurement interval $(2 \mathrm{~h})$. The resulting three means were then averaged to obtain an overall mean estimate for each steer and sample day. Net tissue uptake of $\mathrm{O}_{2}$ and net tissue uptake or release of other metabolites was calculated as the product of arterio-venous $(\mathrm{A}-\mathrm{V})$ concentration difference and blood flow. Fractional uptake (uptake relative to tissue supply) of $\mathrm{O}_{2}$ for the PDV and HQ was calculated as $(\mathrm{A}-\mathrm{V}) / \mathrm{A}$ where $\mathrm{V}$ is the $\mathrm{O}_{2}$ concentration in the portal vein or vena cava respectively. Fractional uptake of $\mathrm{O}_{2}$ by the liver was calculated as:

$$
\frac{\text { hepatic } \mathrm{O}_{2} \text { uptake }}{\left(\left(\mathrm{HA} \text { flow } \times\left[\mathrm{O}_{2}\right]_{\mathrm{HA}}\right)+\left(\text { PDV flow } \times\left[\mathrm{O}_{2}\right]_{\mathrm{P}}\right)\right)} \text {, }
$$

where HA is hepatic artery and $\mathrm{P}$ is portal vein.

\section{Statistical analysis}

Statistical analysis of all variables was performed using a Student's paired $t$ test to compare values obtained during the fed and fasted state (Snedecor \& Cochran, 1967).

\section{RESULTS}

Whole-body measures

Whole-animal responses were similar in Expts 1 and 2 (Table 2). Uptake of $\mathrm{O}_{2}$ and production of $\mathrm{CO}_{2}$ and $\mathrm{CH}_{4}$ were lower $(P<0.001)$ in fasted than in fed steers. The 
Table 2. Whole-body measurements in fed and fasted steers*

\begin{tabular}{|c|c|c|c|c|}
\hline Variable & Fed & Fasted & SED & $\begin{array}{c}\text { Statistical significance } \\
\text { of difference: } P<\end{array}$ \\
\hline \multicolumn{5}{|l|}{ Expt 1} \\
\hline BW (kg) & 339 & 333 & 2 & 0.05 \\
\hline \multicolumn{5}{|l|}{ Gas exchanges $(1 / 2 h)$ : } \\
\hline Oxygen & $197 \cdot 2$ & $131 \cdot 0$ & 7.2 & 0.001 \\
\hline Carbon dioxide & 198.8 & $96 \cdot 1$ & 7.0 & 0.001 \\
\hline Methane & $8 \cdot 2$ & $1 \cdot 0$ & 0.5 & 0.001 \\
\hline RQ & 1.01 & 0.73 & 0.008 & 0.001 \\
\hline \multicolumn{5}{|l|}{ Heat productiont: } \\
\hline $\mathrm{kJ} / \mathrm{d}$ per $\mathrm{kg} \mathrm{BW}$ & $147 \cdot 3$ & $93 \cdot 7$ & $4 \cdot 2$ & 0.001 \\
\hline $\mathrm{kJ} / \mathrm{d}$ per $\mathrm{kg} \mathrm{BW} \mathrm{BW}^{0.75}$ & 632.6 & $400 \cdot 8$ & $19 \cdot 7$ & 0.001 \\
\hline \multicolumn{5}{|l|}{ Expt 2} \\
\hline BW (kg) & 426 & 416 & 2 & $0 \cdot 01$ \\
\hline Heart rate (beats/min) & 81 & 51 & $i$ & 0.001 \\
\hline \multicolumn{5}{|l|}{ Gas exchanges $(1 / 2 \mathrm{~h})$ : } \\
\hline Oxygen & $242 \cdot 8$ & 153.8 & $2 \cdot 3$ & 0.001 \\
\hline Carbon dioxide & $248 \cdot 8$ & 110.8 & 2.6 & 0.001 \\
\hline Methane & $18 \cdot 2$ & 0.9 & 0.6 & 0.001 \\
\hline $\mathrm{RQ}$ & 1.02 & 0.72 & 0.005 & 0.001 \\
\hline \multicolumn{5}{|l|}{ Heat productiont: } \\
\hline $\mathrm{kJ} / \mathrm{d}$ per kg BW & 144.8 & 87.9 & $1 \cdot 2$ & 0.001 \\
\hline $\mathrm{kJ} / \mathrm{d}$ per $\mathrm{kg} \mathrm{BW}^{0.75}$ & $658 \cdot 1$ & 396.6 & $5 \cdot 4$ & 0.001 \\
\hline
\end{tabular}

SED, standard error of the difference between means; BW, body-weight; RQ, respiratory quotient.

* For details of procedures, see p. 401.

$\dagger$ Calculated from $\mathrm{O}_{2}$ consumed and $\mathrm{CO}_{2}$ produced with correction for $\mathrm{CH}_{4}$ production (Brouwer, 1965). Extrapolated to $24 \mathrm{~h}$.

respiratory quotient $(\mathrm{RQ})$ decreased $(P<0.001)$ as well, indicating a change in oxidative substrate. $\mathrm{CH}_{4}$ production and the RQ together suggested attainment of the fasting state. Loss of energy as heat, expressed relative to body weight $(\mathrm{BW})$ or $\mathrm{BW}^{0.75}$ decreased $(P<$ $0 \cdot 001$ ) with fasting.

For Expt $1, \mathrm{O}_{2}$ uptake did not differ across whole-body periods and was $195 \cdot 6,195.8$ and 199.5 litres/h during fed measurements compared with $131 \cdot 8,128.4$ and 132.6 litres/h during fasting (SEM 3.0). For Expt 2, $\mathrm{O}_{2}$ uptake did vary across whole-body periods and was $254 \cdot 4,241 \cdot 0$ and $233 \cdot 1$ litres/h during fed measurements compared with 158.7, 153.1 and $149 \cdot 6$ litres/h during fasting (SEM 2.9).

\section{Tissue blood flow and $\mathrm{O}_{2}$}

In Expt 1, arterial $\mathrm{O}_{2}$ concentration and arterio-portal concentration differences were not changed with fasting (Table 3$)$. Both arterio-hepatic $(P<0.03)$ and portal-hepatic $(P<$ 0 -06) $\mathrm{O}_{2}$ differences increased with fasting, while blood flow in both the PDV $(P<0.004)$ and liver $(P<0.02)$ decreased. The percentage of liver blood flow derived from the PDV was unchanged with treatment, although it tended to be lower during fasting $(85 v .79 \%$ of total flow).

In Expt 2, arterial $\mathrm{O}_{2}$ concentration $(P<0.001)$ and arterio-hepatic $(P<0.07)$, portalhepatic $(P<0.02)$ and arterio-venous $(P<0.02)$ concentration differences increased with fasting. $\mathrm{O}_{2}$ concentration difference across the PDV was unchanged. Blood flow decreased $(P<0.001)$ in all tissue beds measured as did the contribution of PDV blood flow to liver blood flow $(91$ v. $79 \%, P<0.01)$. 
Table 3. Oxygen concentrations $(m M)$, arterio-venous concentration differences $(m M)$, and blood flow $(l / h)$ in fed and fasted steers*

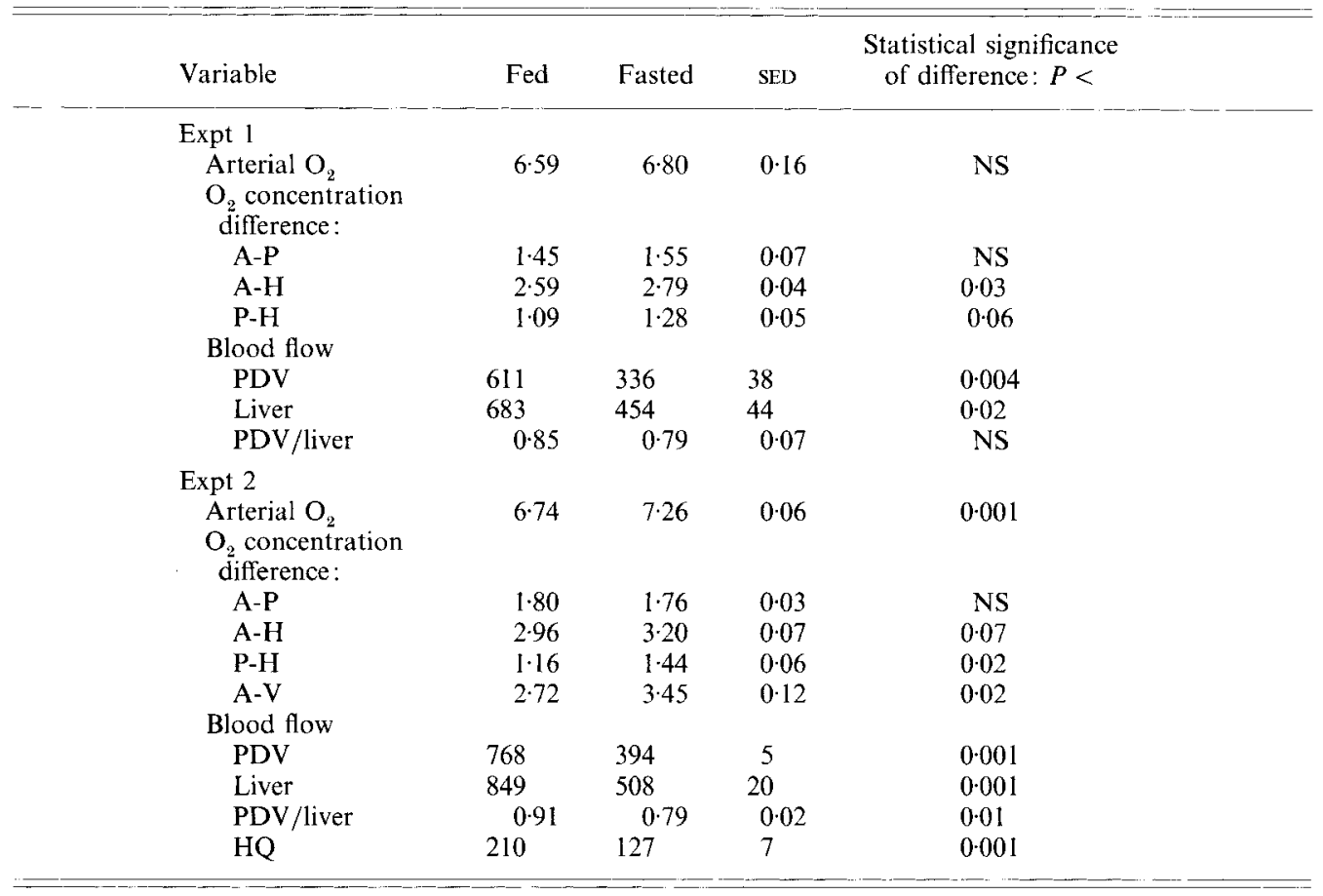

SED, standard error of the difference between means; A, artery; $\mathrm{P}$, portal vein; $\mathrm{H}$, hepatic vein; $\mathrm{V}$, caudal vena cava; PDV, portal-drained viscera; HQ, hindquarters; NS, not significant.

* For details of procedures, see pp. 401-402.

In Expt $1, \mathrm{O}_{2}$ uptake decreased in PDV $(P<0 \cdot 004)$ and total splanchnic tissues $(P<$ $0 \cdot 05$ ) in response to fasting (Table 4). There was an $18 \%$ decrease in liver $\mathrm{O}_{2}$ uptake with fasting, although this was not significant. Fractional uptake of $\mathrm{O}_{2}$ was unchanged in the tissues measured, although it tended to be higher in the liver. In Expt 2, $\mathrm{O}_{2}$ uptake decreased $(P<0.001$ except liver, $P<0.06)$ in all tissues with fasting. Fractional uptake decreased in PDV $(P<0.01)$ and increased $(P<0.05)$ in liver and HQ tissues. The increase in uptake by the liver in Expt 2 was similar to the trend in Expt 1.

Values for tissues and the whole animal were combined to calculate proportional contribution of tissues to whole-animal $\mathrm{O}_{2}$ uptake (Table 5). In Expt 2 the proportional contribution of PDV tissues decreased $(P<0.001)$ and of liver increased $(P<0.02)$ with respect to whole-animal $\mathrm{O}_{2}$ consumption when steers were fasted. Similar trends were apparent in Expt 1.

\section{Net flux of nitrogenous compounds}

Fasting resulted in increased arterial concentration of urea-N $(P<0.05)$ and $\alpha$-amino$\mathrm{N}(P<0.01)$ but not ammonia-N (Table 6$)$. Net flux of these compounds across PDV tissue changed such that release of ammonia-N and $\alpha$-amino-N by the PDV decreased $(P<$ $0.001)$ and transfer of urea-N to the PDV decreased $(P<0.07)$ with fasting. Net flux across the liver was unchanged by fasting except for uptake of ammonia which decreased $(P<$ 0.003 ). 
Table 4. Oxygen uptake $(\mathrm{mmol} / \mathrm{h})$ and fractional uptake in tissues of fed and fasted steers*

\begin{tabular}{|c|c|c|c|c|}
\hline Variable & Fed & Fasted & SED & $\begin{array}{c}\text { Statistical significance } \\
\text { of difference: } P<\end{array}$ \\
\hline \multicolumn{5}{|l|}{ Expt I } \\
\hline \multicolumn{5}{|l|}{$\mathrm{O}_{2}$ uptake $\dagger$} \\
\hline PDV & 876 & 520 & 48 & $0 \cdot 004$ \\
\hline Liver & 900 & 742 & 141 & NS \\
\hline Splanchnic & 1765 & 1269 & 130 & 0.05 \\
\hline \multicolumn{5}{|c|}{ Fractional uptake: } \\
\hline PDV & $2 I \cdot 9$ & $22 \cdot 8$ & $0 \cdot 8$ & NS \\
\hline Livers & $24 \cdot 7$ & $29 \cdot 2$ & $2 \cdot 6$ & NS \\
\hline Splanchnic $\ddagger$ & $39 \cdot 2$ & $42 \cdot 0$ & $1 \cdot 1$ & NS \\
\hline \multicolumn{5}{|l|}{ Expt 2} \\
\hline \multicolumn{5}{|l|}{$\mathrm{O}_{2}$ uptaket } \\
\hline PDV & 1377 & 684 & 21 & $0 \cdot 001$ \\
\hline Liver & 1114 & 911 & 57 & $0 \cdot 06$ \\
\hline Splanchnic & 2486 & 1594 & 70 & $0 \cdot 001$ \\
\hline $\mathrm{HQ}$ & 518 & 357 & 7 & $0 \cdot 001$ \\
\hline \multicolumn{5}{|c|}{ Fractional uptake: } \\
\hline PDV $\ddagger$ & $26 \cdot 7$ & $24 \cdot 2$ & $0 \cdot 4$ & $0.0 \mathrm{I}$ \\
\hline Liver§ & $25 \cdot 9$ & $30 \cdot 7$ & $1 \cdot 1$ & $0 \cdot 03$ \\
\hline Splanchnic & $43 \cdot 9$ & $44 \cdot 0$ & $1 \cdot 0$ & NS \\
\hline $\mathrm{HQ}$ & $41 \cdot 0$ & $46 \cdot 0$ & $1 \cdot 0$ & 0.04 \\
\hline
\end{tabular}

PDV, portal-drained viscera; HQ, hindquarters; NS, not significant.

* For details of procedures, see pp. 401-402.

$\dagger$ Uptake $(\mathrm{mmol} / \mathrm{h})=$ arterio-venous concentration difference $(\mathrm{mm}) \times$ blood flow $(1 / \mathrm{h})$.

$¥$ Fractional uptake $=\left[\mathrm{O}_{3}\right]_{A-X} /\left[\mathrm{O}_{2}\right]_{\mathrm{A}} \times 100$ where $\mathrm{A}$ is arterial $\mathrm{O}_{2}$ concentration, $X$ is portal vein $\mathrm{O}_{2}$ concentration for PDV, hepatic vein $\mathrm{O}_{2}$ concentration for splanchnic, and vena cava $\mathrm{O}_{2}$ concentration for $\mathrm{HQ}$.

$\S$ Fractional uptake $=$ liver $\mathrm{O}_{2}$ uptake $/\left(\left(\mathrm{HA}\right.\right.$ flow $\left.\times\left[\mathrm{O}_{2}\right]_{\mathrm{HA}}\right)+\left(\mathrm{PDV}\right.$ flow $\left.\left.\times\left[\mathrm{O}_{2}\right]_{\mathrm{P}}\right)\right) \times 100$ where $\mathrm{HA}$ is hepatic artery and $\mathrm{P}$ is portal vein.

Table 5. Tissue oxygen uptake as a percentage of whole-body (WB) oxygen uptake expressed on an absolute and incremental basis in fed and fasted steers $\dagger$

\begin{tabular}{|c|c|c|c|c|c|c|}
\hline \multirow[b]{2}{*}{ Variable } & \multicolumn{2}{|c|}{ Absolute* } & \multirow[b]{2}{*}{ SED } & \multirow{2}{*}{$\begin{array}{c}\text { Statistical } \\
\text { significance } \\
\text { of difference: } \\
P<\end{array}$} & \multicolumn{2}{|c|}{ Incremental* } \\
\hline & Fed & Fasted & & & Mean & SEM \\
\hline \multicolumn{7}{|l|}{ Expt I } \\
\hline PDV & $20 \cdot 0$ & 17.8 & $1 \cdot 2$ & NS & $27 \cdot 2$ & 6.7 \\
\hline Liver & $20 \cdot 7$ & $25 \cdot 2$ & $4 \cdot 1$ & NS & $8 \cdot 1$ & $17 \cdot 5$ \\
\hline Splanchnic & $40 \cdot 8$ & $43 \cdot 3$ & $3 \cdot 1$ & NS & $36 \cdot 2$ & $13 \cdot 2$ \\
\hline \multicolumn{7}{|l|}{ Expt 2} \\
\hline PDV & $25 \cdot 4$ & $19 \cdot 9$ & $0 \cdot 3$ & $0 \cdot 001$ & $34 \cdot 4$ & $1 \cdot 4$ \\
\hline Liver & $20 \cdot 5$ & $26 \cdot 4$ & $1 \cdot 3$ & 0.02 & $9 \cdot 5$ & $3 \cdot 7$ \\
\hline Splanchnic & $45 \cdot 8$ & $46 \cdot 4$ & $1 \cdot 4$ & NS & $43 \cdot 7$ & 3.6 \\
\hline $\mathrm{HQ}$ & 9.6 & 10.5 & $0 \cdot 4$ & NS & $8 \cdot 0$ & $0 \cdot 3$ \\
\hline
\end{tabular}

SED, standard error of the difference between means; SEM, standard error of the mean; PDV, portal-drained viscera; HQ, hindquarters; NS, not significant.

* Absolute basis $=($ tissue $/ W B) \times 100 ;$ Incremental $=\left(\left(\right.\right.$ tissue $_{\text {fed }}-$ tissue $\left.\left._{\text {fasted }}\right) /\left(W_{\text {fed }}-W_{\text {fasted }}\right)\right) \times 100$.

$\dagger$ For details of procedures, see pp. 401-402. 
Table 6. Expt2. Arterial concentration $(\mathrm{mM})$ and net flux (mmol/h) of nitrogenous variables in fed and fasted steers*

\begin{tabular}{|c|c|c|c|c|}
\hline Variable & Fed & Fasted & SED & $\begin{array}{c}\text { Statistical significance } \\
\text { of difference: } P<\end{array}$ \\
\hline \multicolumn{5}{|l|}{ Concentration } \\
\hline Ammonia & 0.374 & 0.409 & 0.016 & NS \\
\hline Urea-nitrogen & $5 \cdot 83$ & $7 \cdot 19$ & 0.36 & 0.05 \\
\hline$\alpha$-Amino-N & $3 \cdot 28$ & 3.50 & 0.04 & 0.01 \\
\hline \multicolumn{5}{|l|}{ Net flux $\dagger$} \\
\hline \multicolumn{5}{|l|}{ PDV } \\
\hline Ammonia & -185 & -78 & 11 & 0.001 \\
\hline Urea-N & 123 & 39 & 25 & 0.07 \\
\hline$\alpha$-Amino- $N$ & -119 & 4 & 6 & 0.001 \\
\hline \multicolumn{5}{|l|}{ Liver } \\
\hline Ammonia & 190 & 100 & 12 & 0.003 \\
\hline Urea-N & -238 & -183 & 23 & NS \\
\hline$\alpha$-Amino- $N$ & 61 & 87 & 11 & NS \\
\hline
\end{tabular}

SED, standard error of the difference between means; PDV, portal-drained viscera; NS, not significant.

* For details of procedures, see pp. 401-402.

$\dagger$ Net flux $(\mathrm{mmol} / \mathrm{h})=$ arterio-venous concentration difference $(\mathrm{mm}) \times$ blood flow $(1 / \mathrm{h})$. Positive number indicates net uptake, a negative number indicates net release.

\section{DISCUSSION}

The values for whole-animal gas exchange or FHP are similar in magnitude to those previously reported for fasted cattle by Rumsey et al. (1980), and on the low end of the range reported by Webster et al. (1974). They are, however, higher than equations derived by the Agricultural Research Council (1980) which estimate FHP as a function of BW $^{\mathbf{0 . 6 7}}$ and would equate to $26 \mathrm{MJ} / \mathrm{d}$ for Expt 1 and $30 \cdot 1 \mathrm{MJ} / \mathrm{d}$ for Expt 2. The values for heat production in fed and fasted steers in the present study compare well with those of Lobley et al. (1987). On average they observed heat production of $65 \cdot 9,52 \cdot 4$ and $39 \cdot 6 \mathrm{MJ} / \mathrm{d}$ for steers fed at $1.6 \mathrm{M}, 1.0 \mathrm{M}$ or fasted respectively (where $\mathrm{M}$ is the $\mathrm{ME}$ calculated for zero energy retention). Their steers were slightly heavier than those of Expt 2 . The level of energy intake before fasting has been shown to affect FHP (for review, see Ferrell, 1988); however, the steers of Lobley et al. (1987) were fed on a maintenance ration for 3 weeks before fasting.

In concert with observed changes in heart rate (Table 1 and Rumsey et al. 1980) and trends in cardiac output (Huntington et al. 1990) in fed $v$. fasted steers, blood flow to all tissue beds declined with fasting. The decrease was greatest for the PDV. There was also a shift in the proportion of liver blood derived from PDV tissues and the hepatic artery (significant in Expt 2, trend in Expt 1) such that the hepatic arterial contribution increased with fasting. Lomax \& Baird (1983) observed a greater decline in portal than hepatic blood flow in non-lactating dairy cows in response to fasting. Hepatic arterial flow was unchanged by fasting in the study of Lomax \& Baird (1983). Along with the decrease in blood flow, arterio-venous concentration difference of $\mathrm{O}_{2}$ increased across all tissue beds except the PDV. The increase in $\mathrm{O}_{2}$ concentration difference across tissues other than PDV reflects the greater decrease in blood flow than $\mathrm{O}_{2}$ uptake across these tissues with fasting. In general, Burrin et al. (1989) observed changes in blood flow but not arterio-venous concentration difference in lambs fed at maintenance or ad lib.

Regression of $\mathrm{O}_{2}$ uptake $v . \mathrm{O}_{2}$ supply across both experiments (Fig. 1) showed a strong positive relationship $(P<0.01)$ between these variables in all three vascular beds for fed and fasted steers. These observations are similar to those of Edelstone \& Holzman (1981) 
(a) Portal-drained viscera।

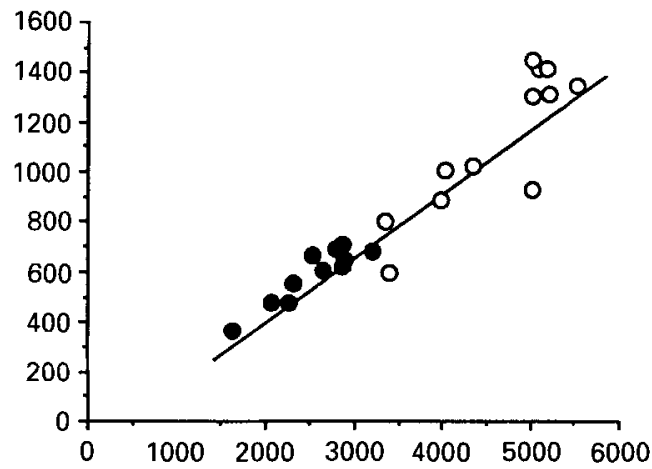

(b) Liver

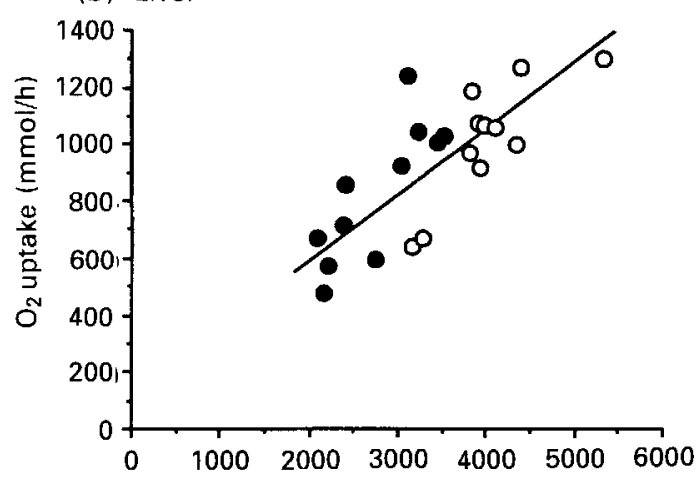

(c) Hindquarters

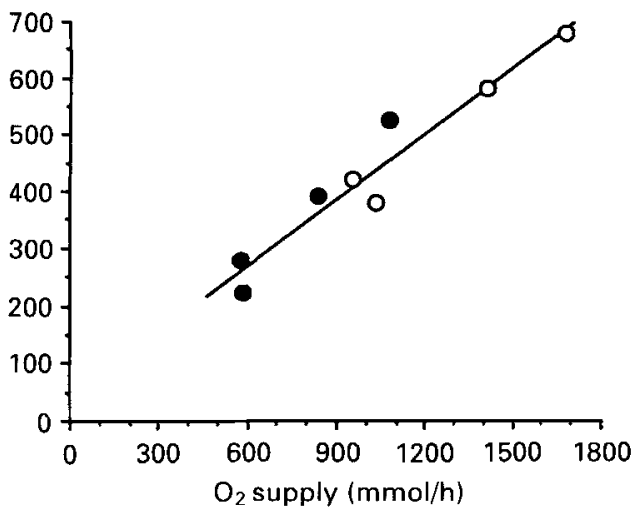

Fig. 1. Relation between oxygen uptake and $\mathrm{O}_{2}$ supply in $(a)$ portal-drained viscera $y=0 \cdot 271 x-105 \cdot 5, R^{2} 0 \cdot 90$, SE 0.019 , residual standard deviation (RSD) $110 \cdot 00,(b)$ liver $y=0 \cdot 225 x+167 \cdot 5, R^{2} 0 \cdot 59$, SE $0 \cdot 040$, RSD 154.7; and (c) hindquarters $y=0.387 x+44 \cdot 5, R^{2} 0.92$, SE $0 \cdot 043$, RSD $43 \cdot 3$ tissues in fed $(O)$ and fasted (O) steers. Values were pooled across Expts 1 and 2. For details of procedures, see pp. 401-402.

for PDV of newborn lambs but differ in that they observed no relation between $\mathrm{O}_{2}$ uptake by the liver and either blood flow or $\mathrm{O}_{2}$ supply. In addition, Edelstone \& Holzman (1981) observed no relationship between $\mathrm{O}_{2}$ supply and extraction in the gut of newborn lambs that were fed or fasted but a negative relationship between supply and extraction in the 
liver. Across both experiments $\mathrm{O}_{2}$ extraction by the PDV, liver or $\mathrm{HQ}$ did not vary with blood flow or $\mathrm{O}_{2}$ supply ( $P>0 \cdot 10$, values not shown). In general, across the tissues studied, extraction was higher in the HQ $(38.7 \%)$ than the PDV $(27.1 \%)$ or liver $(22.5 \%)$, suggesting an inverse relationship between extraction and supply (or flow). $\mathrm{O}_{2}$ extraction by the HQ decreased in steers, concomitant with increased blood flow and increased $\mathrm{O}_{2}$ uptake in response to clenbuterol (Eisemann et al. 1988). The observation that changes in the PDV differ from those of the other tissues suggests interrelationships among supply, extraction and metabolic need.

Comparison of whole-body $\mathrm{O}_{2}$ consumption in fed $v$. fasted cattle in these two experiments indicates an increase of 1.5- to 1.6-fold in the fed state. The tissue bed showing the largest change was the PDV, which increased from 1.7- to 2-fold (Expts 1 and 2, respectively), whereas the smallest change was in liver $\mathrm{O}_{2}$ use which increased 1-2-fold. Changes in HQ tissues reflected the average of the whole body. The increase in PDV accounted for $27-34 \%$ and in splanchnic tissues accounted for 36-44\% (Expts 1 and 2, respectively; Table 5) of the increase for the whole body. The variation in tissue change relative to the whole body is reflected in the proportional calculations (Table 5) where trends were evident in Expt 1 and significant changes were observed in Expt 2. The major difference between the two experiments is in the PDV which may relate to the higher level of feeding in Expt 2 or the differences between diets.

Lomax \& Baird (1983) observed a decline in $\mathrm{O}_{2}$ uptake of both PDV and hepatic tissues in fasted dairy cattle that was of similar magnitude in the two tissues. A positive relation between ME intake and $\mathrm{O}_{2}$ uptake by the PDV (Webster et al. 1975; Burrin et al. 1989) and liver (Burrin et al. 1989) in lambs and PDV of steers (Huntington et al. 1988) have been reported. McBride \& Milligan (1985 $b$ ) observed no change in total $\mathrm{O}_{2}$ uptake of duodenal mucosa per unit dry weight (measured in vitro) in response to level of feeding, including a $48 \mathrm{~h}$ fast, in sheep. They (McBride \& Milligan, 1985a) also observed no change in $\mathrm{O}_{2}$ uptake by hepatocytes per unit dry weight from sheep fed either at maintenance or fasted for $5 \mathrm{~d}$. Similarly, Burrin et al. (1988), comparing fed and starved rats, showed no change in $\mathrm{O}_{2}$ consumption of hepatocytes per unit weight. As reviewed by Ferrell (1988), considerable information exists to demonstrate a positive relationship between level of nutrition and visceral organ mass. These findings imply that changes in $\mathrm{O}_{2}$ consumption with level of feeding relate more to changes in tissue mass than metabolic activity. These approaches in vitro, however, may not reflect the situation in vivo.

Energy-requiring processes in body tissues include macromolecular turnover, transport and substrate cycling (for review, see Summers et al. 1988). Webster (1980) discussed some of the processes occurring in the gut that contribute to $\mathrm{O}_{2}$ use by these tissues. He calculated that protein synthesis could account for $50 \%$ of the aerobic $\mathrm{O}_{2}$ use by gut tissues. McNurlan et al. (1979) showed both a decrease in fractional rate and absolute rate of protein synthesis in the jejunal mucosa and liver of starved rats. In cattle (Lobley et al. 1987), whole-body protein synthesis declined with decreasing level of intake including fasting; however, heat production attributed to protein synthesis relative to total heat production did not change with level of intake. Protein oxidation declined with level of intake above and including maintenance and increased with fasting. Thus, amino acid oxidation is one process that increases with fasting. The whole-body measurements of Lobley et al. (1987) may hide important differential effects in specific body tissues that explain the proportional changes seen in response to fasting in Expt 2 and the trends in Expt 1 .

$\mathrm{O}_{2}$ consumption measures in hepatocytes (McBride \& Milligan, 1985a) and duodenal mucosa (McBride \& Milligan, 1985b) showed that ouabain-sensitive $\mathrm{O}_{2}$ consumption was a greater proportion of total $\mathrm{O}_{2}$ consumption in fed than fasted sheep, demonstrating a 
shift in energy expenditure with fasting. These findings give no indication of other metabolic processes, independent of $\mathrm{Na}^{+}, \mathrm{K}^{+}$-ATPase, that show a proportional increase with fasting to account for the similarity in total $\mathrm{O}_{2}$ consumption per unit weight.

The information on $\mathrm{N}$ flux across PDV and liver tissues gives some rationale for the observations on $\mathrm{O}_{2}$ use across these tissues. Net flux of $\alpha$-amino- $\mathrm{N}$ across the PDV was not different from zero in fasted steers and yet uptake of $\alpha$-amino- $\mathrm{N}$ by the liver was unchanged, indicating a change in origin of $\alpha$-amino- $N$ from the gut to the periphery. Arterial supply of $\alpha$-amino- $N$ to the liver increased from 266 to $399 \mathrm{mmol} / \mathrm{h}$ during fasting. Heitmann \& Bergman (1980) in sheep and Lomax \& Baird (1983) in dairy cattle showed little change in amino acid uptake by hepatic tissues in fasted animals despite the cessation of absorption from the PDV. Amino acids may be used for synthesis of liver and plasma proteins, they may be completely oxidized or the carbon skeletons used for gluconeogenesis. On a proportional basis, $\mathrm{N}$ from uptake of $\alpha$-amino- $\mathrm{N}$ by the liver could contribute 0.26 to urea- $\mathrm{N}$ output during the fed state, increasing to 0.48 during fasting, while proportional contribution of $\mathrm{NH}_{3}-\mathrm{N}$ uptake to urea- $\mathrm{N}$ output decreased from 0.80 in the fed state to 0.55 during fasting. In part this reflects a decrease in $\mathrm{NH}_{3}-\mathrm{N}$ uptake without a similar decrease in urea- $\mathrm{N}$ output during fasting as well as a trend for higher uptake of $\alpha$-amino- $\mathrm{N}$ during fasting. These trends are consistent with increased amino acid oxidation. Similarly transfer of urea to the PDV decreased from 0.52 of hepatic output in the fed state to 0.21 during fasting. On a net $\mathrm{N}$ basis for each mmol urea- $\mathrm{N}$ transferred to the gut, $2 \cdot 0 \mathrm{mmol} \mathrm{NH}_{3}-\mathrm{N}$ were absorbed during fasting and only 1.5 during the fed state, suggesting greater microbial use of the recycled $\mathrm{N}$ in the fed state. Findings of Bergman \& Wolff (1971) showed that net absorption of propionate by the PDV ceases in sheep fasted for $3 \mathrm{~d}$ thereby increasing the quantitative significance of amino acids for gluconeogenesis, although glucose output by the liver declines with fasting as well (Bergman et al. 1974). Similar observations were reported in cows (Lomax \& Baird, 1983). Therefore, while digestive and absorptive functions decline in PDV, diverse metabolic functions continue in the liver.

The trend toward a decrease in hepatic urea output was similar to the decline in $\mathrm{O}_{2}$ use by the liver during fasting, resulting in a similar proportional contribution of urea production to energy use by the liver. Using values of 4 ATP per mol urea synthesized and 6 ATP per mol $\mathrm{O}_{2}$ consumed, approximately $7 \cdot 1$ and $6.7 \%$ of the $\mathrm{O}_{2}$ used by the liver could be attributed to urea production for fed and fasted steers respectively. This implies that urea synthesis does not make a major contribution to liver energy expenditure. These estimates do not account for a decrease in ATP produced per mol $\mathrm{O}_{2}$ consumed in general or in response to fasting. Using the previous assumptions, Huntington \& Reynolds (1987) suggested a value of approximately $8.5 \%$ (the original value reported was for urea- $\mathrm{N}$, assuming 4.8 ATP per mol urea and 5 ATP per mol $\mathrm{O}_{2}$ ) in lactating cows, and Summers et al. (1988) calculated $812 \%$ based on findings of Rabkin \& Blum (1985) from rat hepatocytes.

The proportional contribution of tissue $\mathrm{O}_{2}$ uptake to whole-body $\mathrm{O}_{2}$ uptake was similar in the two experiments except for slightly higher values in Expt 2 for the PDV ( 20 v. $25 \%)$. The diet in Expt 2 was higher in forage than that of Expt 1 and fed at a slightly higher level. Either of these could alter proportional contribution of the PDV to whole-animal energy use. The value for contribution of the PDV was similar to the value of $18 \%$ reported for dairy cows (Huntington \& Tyrrell, 1985) and 20\% for lambs (Webster, 1980). Huntington et al. (1988) reported values from 23 to $29 \%$ in beef steers. Values for percentage contribution of liver, $2026 \%$, were slightly lower than values of $24-31 \%$ in beef steers reported by Huntington et al. (1990) and higher than those of Thompson \& Bell (1976) who reported $1618 \%$ in lambs. It is noteworthy that the total contribution of splanchnic tissues to whole-body $\mathrm{O}_{2}$ use remained constant with fasting despite the change in the individual 
components. The high contribution of these tissues to $\mathrm{O}_{2}$ use in the body relative to their contribution to BW was previously discussed (for review, see Huntington \& Reynolds, 1987). In contrast, tissues of the HQ contributed only $10 \%$ to $\mathrm{O}_{2}$ use. In steers of $350 \mathrm{~kg}$ live weight, HQ tissues represented approximately $28 \%$ of empty BW (J. H. Eisemann, G. B. Huntington and D. R. Catherman, unpublished results). Therefore, while the PDV overcontributes and the HQ undercontributes, each by a factor of $2-3$, the liver makes the most disproportionate contribution to $\mathrm{O}_{2}$ use.

In conclusion, the findings presented here quantify blood flow and $\mathrm{O}_{2}$ use in body tissues of fed and fasted cattle. Blood flow to and $\mathrm{O}_{2}$ uptake by all tissues measured decreased as did $\mathrm{O}_{2}$ uptake by the whole body during fasting. Proportional contribution of $\mathrm{O}_{2}$ use by major tissues varied between fed and fasted states (Expt 2) such that the contribution of PDV tissues decreased and of liver tissue increased during fasting. Therefore, food supply altered the partition of energy use as well as the total. Because proportional contribution of tissues may change with fasting, relationships observed in the fasting state may not reflect those present in the normal anabolic situation. Similarly, proportional relationships may vary with level of anabolism, and, thus, should not be extrapolated beyond conditions under which they are measured.

The authors thank Dr G. B. Huntington for assistance with surgical preparation of the steers; K. Sorenson for care and feeding of the steers; and C. Felber and E. Shetler for technical assistance.

Mention of trade names, proprietary products or specific equipment does not constitute a guarantee or warranty of the product by the USDA and does not imply its approval to the exclusion of other products that may also be suitable.

\section{REFERENCES}

Agricultural Research Council (1980). The Nutrient Requirements of Ruminant Livestock. Slough: Commonwealth Agricultural Bureaux.

Bergman, E. N., Brockman, R. P. \& Kaufman, C. F. (1974). Glucose metabolism in ruminants: comparison of whole-body turnover with production by gut, liver and kidneys. Federation Proceedings 33, 1849-1854.

Bergman, E. N. \& Wolff, J. E. (1971). Metabolism of volatile fatty acids by liver and portal-drained viscera in sheep. American Journal of Physiology 221, 586-592.

Broderick, G. A. \& Kang, J. H. (1980). Automated simultaneous determination of ammonia and total amino acids in ruminal fluid and in vitro media. Journal of Dairy Science 63, 64-75.

Brouwer, E. (1965). Report of subcommittee on constants and factors in energy metabolism. In Energy Metabolism. Proceedings of the 3rd Symposium on Energy Metabolism, European Association of Animal Production Publication no. 11, pp. 441-443 [K. L. Blaxter, editor]. New York: Academic Press.

Burrin, D. G., Britton, R. A. \& Ferrell, C. L. (1988). Size and metabolic activity of visceral organs in fed and fasted rats. Journal of Nutrition 118, 1547-1552.

Burrin, D. G., Ferrell, C. L., Eisemann, J. H., Britton, R. A. \& Nienaber, J. A. (1989). Effect of plane of nutrition on splanchnic blood flow and oxygen consumption in sheep. British Journal of Nutrition 62, 23--34.

Edelstone, D. I. \& Holzman, I. R. (1981). Oxygen consumption by the gastrointestinal tract and liver in conscious newborn lambs. American Journal of Physiology 240, G297-G304.

Eisemann, J. H., Huntington, G. B. \& Ferrell, C. L. (1988). Effects of dietary clenbuterol on metabolism of the hindquarters in steers. Journal of Animal Science 66, 342-353.

Ferrell, C. L. (1988). Contribution of visceral organs to animal energy expenditures. Current concepts of animal growth. IV. Journal of Animal Science 66, Suppl. 3, 23-34.

Heitmann, R. N. \& Bergman, E. N. (1980). Integration of amino acid metabolism in sheep: effects of fasting and acidosis. American Journal of Physiology 239, E248-E254.

Huntington, G. B., Eisemann, J. H. \& Whitt, J. M. (1990). Portal blood flow in beef steers-comparison of techniques and relation to hepatic blood flow, cardiac output and oxygen uptake. Journal of Animal Science 68 , $1666-1673$.

Huntington, G. B. \& Reynolds, C. K. (1987). Oxygen consumption and metabolite flux of bovine portal-drained viscera. Journal of Nutrition 117, 1167-1173.

Huntington, G. B., Reynolds, C. K. \& Stroud, B. H. (1989). Techniques for measuring blood flow in splanchnic tissues of cattle. Journal of Dairy Science 72, 1583-1595. 
Huntington, G. B. \& Tyrrell, H. F. (1985). Oxygen consumption by portal-drained viscera of cattle : comparison of analytical methods and relationship to whole body oxygen consumption. Journal of Dairy Science 68 , $2727-2731$.

Huntington, G. B., Varga, G. A, Glenn, B. P. \& Waldo, D. R. (1988). Net absorption and oxygen consumption by Holstein steers fed alfalfa or orchardgrass silage at two equalized intakes. Journal of Animal Science 66, $1292-1302$.

Lobley, G. E., Connell, A. \& Buchan, V. (1987). Effect of food intake on protein and energy metabolism in finishing beef steers. British Journal of Nutrition 57, 457-465.

Lomax, M. A. \& Baird, G. D. (1983). Blood flow and nutrient exchange across the liver and gut of the dairy cow. Effects of lactation and fasting. British Journal of Nutrition 49, 481-496.

McBride, B. W. \& Milligan, L. P. (1985a). Magnitude of ouabain-sensitive respiration in the liver of growing, lactating and starved sheep. British Journal of Nutrition 54, 293-303.

McBride, B. W. \& Milligan, L. P. (1985b). Influence of feed intake and starvation on the magnitude of $\mathrm{Na}^{+}, \mathrm{K}^{+}$. ATPase (EC 3.6.1.3)-dependent respiration in duodenal mucosa of sheep. British Journal of Nutrition 53, 605-614.

McNurlan, M. A., Tomkins, A. M. \& Garlick, P. J. (1979). The effect of starvation on the rate of protein synthesis in rat liver and small intestine. Biochemical Journal 178, 373-379.

National Research Council (1984). Nutrient Requirements of Beef Cattle, 6th rev. ed. Washington, DC: National Academy Press.

Nienaber, J. A. \& Maddy, A. L. (1985). Temperature controlled multiple chamber indirect calorimeter - design and operation. American Society of Agricultural Engineers 28, 555-560.

Rabkin, M. \& Blum, J. J. (1985). Quantitative analysis of intermediary metabolism in hepatocytes incubated in the presence and absence of glucagon with a substrate mixture containing glucose, ribose, fructose, alanine and acetate. Biochemical Journal 255, 761-786.

Rumsey, T. S., Tyrrell, H. F. \& Moe, P. W. (1980). Effect of diethylstilbestrol and Synovex-S on fasting metabolism measurements of beef steers. Journal of Animal Science 50, 160-166.

Snedecor, G. W. \& Cochran, W. G. (1967). Statistical Methods. Ames, IA : Iowa State University Press.

Summers, M., McBride, B.W. \& Milligan, L. P. (1988). Components of basal energy expenditure. In Aspects of Digestive Physiology in Ruminants, pp. 257-285 [A. Dobson and M. J. Dobson, editors]. Ithaca, NY: Comstock Publishing Associates.

Technicon Industrial Systems (1972). Para-amino-hippuric acid, Technicon Industrial Method no. 216-72T. Tarrytown, NY: Technicon Industrial Systems.

Technicon Industrial Systems (1974). Ammonia, Technicon Industrial Method no. 337-747: Tarrytown, NY: Technicon Industrial Systems.

Technicon Industrial Systems (1977). Urea nitrogen, Technicon Industrial Method no. 339-01. Tarrytown, NY: Technicon Industrial Systems.

Thompson, G. E. \& Bell, A.W. (1976). The energy metabolism of the liver measured in vivo during cold exposure of sheep. In Energy Metabolism of Farm Animals. European Association of Animal Production Publication no. 19, pp. 37.40 [M. Vermorel, editor]. Clermont-Ferrand, France: G. de Bussac.

Webster, A. J. F. (1980). Energy cost of digestion and metabolism in the gut. In Digestive Physiology and Metabolism in Ruminants, pp. 469-484 [Y. Ruckebusch and P. Thivend, editors]. Westport, CT: AVI Publishing Company, Inc.

Webster, A. J. F., Brockway, J. M. \& Smith, J. S. (1974). Prediction of the energy requirements for growth in beef cattle. 1. The irrelevance of fasting metabolism. Animal Production 19, 127-139.

Webster, A. J. F., Osuji, P. O., White, F. \& Ingram, J. F. (1975). The influence of food intake on portal blood flow and heat production in the digestive tract of sheep. British Journal of Nutrition 34, 125. 139. 